\title{
The Social Construction of City: Taipei in Human Condition
}

\author{
Chia-ching Lin \\ Yu Da University of Science and Technology, Miaoli, \\ Taiwan
}

\section{Feng-chia Li}

Jen-teh College of Medicine, Nursing and Management,

Miaoli, Taiwan

\begin{abstract}
This paper tries to discuss everyday life and its relation to urban experiences in different aspects of Taipei City in Human Condition, performed by Greenray Theatre in Taiwan since 2001. The serial play, including six parts, displays the life of ordinary people, primarily the middle and labor classes. Historically, Human Condition tells about Taiwanese' life from the period of Japanese occupation in Taiwan to the present day. The public's everyday life and their cultural activities are delicately represented on the stage. Human Condition especially focuses on people living in Taipei city, the capital and most populated place of the country. In different historical periods and political atmospheres, the characters' economic and social activities, nostalgic feelings about the past, passions for love and friendship, and awakening of fighting for humanity and freedom construct their social positions as well as establish different aspects of Taipei. We can see the transformation of the city by means of people's social relationships and economic activities. Drawing on Henri Lefebvre’s concept of everyday life as rhythmic movement and spatial practice in the process of urbanization, this paper aims at studying the characters' social practice that defines their position and formation of identity within place. Human Condition unravels the characters' connection and disconnection from place in each period of Taiwan's historical and political conditions. The life in Taipei differs from each historical, economic, and political system that defines people's attitudes and perspectives toward this land. The characters within every historical background and political system tell us what Taipei represents and symbolizes to people. The transition of Taipei produces impacts on people that endow them with different personalities and perspectives toward life. As globalization invades into this city, the definition of human in city life has to be reconsidered. As a place of encounter, accumulation of cultural hybridity in Taipei formulates multiple dispositions and social structures. By analyzing the characters represented in every historical period of Taipei, this article interrogates to what extent of “in-place” or "out-of-place” of the characters is interpreted in this space and, in the progress of urbanized development of Taipei, what the value is to affect and connect people's relationships.
\end{abstract}

Keywords: Human Condition, Greenray Theatre, Taipei, human, city life

\section{Introduction}

Human Condition, created by Nien-jen Wu, a famous playwright and director in Taiwan, is a serial play including six parts, staged by Greenray Theatre since 2001. This play presents the middle-class life in different

Chia-ching Lin, Ph.D., assistant professor, Department of Applied English, Yu Da University of Science and Technology.

Feng-chia Li, assistant professor, Department of Information Management, Jen-teh College of Medicine, Nursing and Management.

${ }^{1}$ The latest part six is going to be on stage in the end of 2014. 
historical periods of Taiwan, from Japanese occupation to the present day. Taking Taipei as its background living space, the play shows how people deal with their relationships with family and friends in the historical transition of this city. Immigrants from Mainland China learn to face conflicts and come to compromise with other races. Attitudes towards life are disclosed, influenced by different historical, cultural, political, social, and economic activities.

This article investigates Taipei in different periods offered in this play. By employing the first four parts as the examples, the author explores the urban experiences of everyday life in this city. In light of Henri Lefebvre's concepts on space and city and other related theories, it argues that humanity and morality are emphasized even though the rapid transformation and development of the city change the structure of the society and people's social relationships.

\section{Theory on Space}

Lefebvre thinks that space is full of social practices. It is produced and productive, "simultaneously material object or product, the medium of social relations, and the reproducer of material objects and social relations" (Gottdiener, 1985, p. 129). It is an abstraction which is composed of discourses and ideologies. In order to understand space, we need to know how space is produced as a "multimanifested concrete abstraction" (Gottdiener, 1985, p. 129). Space is an abstraction, enclosed by differences discourses and ideologies in which the domination is thus produced to control our everyday life. It requires a dialectical point of view to grasp space since it is an abstraction.

To appropriate space is to endow it as meanings. Space is not fixed but unstable. Lefebvre's account of space is connected to social elements; the appropriation of space is influenced by political, economic, social, and cultural activities. The production of space is, contended by Lefebvre, "spatializing a social activity" (Stanek, 2011, p. 103). Space with triad dimensional meanings is discussed in Lefebvre's writing in which he regards space as different meanings based on the practical and symbolic usages given by those who organize it. He sees capitalism as the important element of increasing uneven distribution and urbanization. The domination-subordination relationship is in the exercise of power over space by those who control the capital. City is an instrument for capitalists' production and reproduction as well as for homogeneity under global economic activities. City space, as Harvey contends, is a space with materials and social matters. The city itself is “a locus and a stabilizer of accumulation and its contradictions" (Harvey, 1973, pp. 203, 216). People's life is guided by the rhythm of capitalism. Modernization implies commodification in everyday life. Thus Lefebvre proposes dialectic means on everyday life because our everyday experience has been dominated and ossified in the development of capitalism. In the relations of production and reproduction, humans and their labor are alienated. People do not respond to any enforcement or difference in their living experience. Lefebvre suggests that everyday life, the essence of space, should be seen as a conglomeration of encounters and differences. The everyday practice should be concerned about differentiation and de-alienation by each moment. Lefebvre takes everyday life is composed of rhythmic moments where people deal with their repetitive social practices. In these recurrences, differences are found and for Lefebvre, the critique and correction of everyday life will lead to a revolution. By supposing space as an abstraction, Lefebvre regards everyday life as a system full of signs and symbols that construct cultural forms and discourses, making the world collaged by fragmental pieces and 
moments. To study the signs and symbols, Lefebvre points out, is to have critique and reflection of modernization and capitalism imposed on our living space. Lefebvre thinks that the space should be a dynamic power that continuously creates new and unpredictable conflicts for people to overcome. Multiplicity and the "right to difference" should be emphasized when we want to move on. In Lefebvre's words, city is a place of "encounter, of gatherings and of jouissance" (Lefebvre, 1996, p. 27). The encounters and gatherings of city lead to various aspects of everyday life that raises many ideas and discourses. City is an artistic work, produced by its multiple activities and social relationships. Therefore, Lefebvre emphasizes that differences should be respected and from that we find the possibility of revolution to improve the space we live so that we can restore to a more humane way of life in the face of cold capitalism and its homogenized, commodified and exchange-valued consumer society.

\section{Brief Introduction of Human Condition}

Part one of Human Condition was first staged in 2001. It is a comedy started by the female leading character, A-mei, a high school student whose family is one of the typical Taiwanese middle-class families during the economic prosperity of Taiwan. It is an era that Taiwanese people were crazy for Liu-he lottery, an illegal gambling activity. A-mei, after school, has to use the computer to make the bets for her neighbors. Hilariously, her father, as a village chief, claims that it is a "service" for his villagers. Obsessed within the lottery, her father asks A-mei alone to worship her passed grandmother on Tomb-sweeping Day, a traditional festival when people worship their ancestors. After A-mei comes back from the cemetery, she is possessed by the grandmother's spirit. In A-mei's body, the grandmother, Tsuru, tries to instruct A-mei's father to do the correct thing for the family. She also wants to accomplish one wish when she was alive: expressing her gratitude for the man, Katsu, who helped her after her husband died. Because of Tsuru's return, the misunderstanding between mother and son or friends in the community is compromised.

The second part of Human Condition, subtitled as She and the Men in Her Life, starts from the end of Japanese occupation to the modern time in Taipei. The 228 Event, the violent conflict between Kuomintang ${ }^{2}$ and Taiwanese people, unravels the story of the leading female character, Yuki, whose family is closely related to Japan authority during the occupation. After the withdrawal of Japan government, for enlarging the family business, Yuki’s father asks her to marry to the so-called "half-Han people": originally being Taiwanese, they resided in Mainland China and came back to Taiwan in 1949, when Kuomintang army was defeated by Chinese Communist Party. For keeping the promise to protect those victims who were buried by her and her mother during the 228 Event in the backyard of the house, Yuki insists to maintain the completion of the house instead of selling it despite of her husband and son's bad intention of trying to make an exchange just for self-interests in business and political relationships.

The third part is about Taiwan's progressing in heavy industry in 1970s. Three young men from the countryside come to Taipei for better job opportunities. They all love the girl, A-ling, who later is attacked by the factory owner. One of the young men, A-rong, is put into jail for killing the factory owner. A-chia, one of the young men, marries A-ling who is pregnant because of the rape. Another one, A-sheng, pretending to be A-ling,

\footnotetext{
${ }^{2}$ Kuomintang is literally Chinese National People’s Party.
} 
writes letters to A-rong. After a few years passed, the characters come back together, memorizing the old time.

Part four shows modern Taipei by presenting two sisters' stories. Mei-nu, the older sister, is optimistic and kind-hearted. Mei-chen, the younger sister, is pessimistic, always complaining about life although she earns more money and has higher social position than her sister. Mei-chen disdains Mei-nu not being aggressive. However, when Mei-nu has a happy love life, Mei-chen feels jealous and even tries to ruin it. Mei-nu in the end does not blame her but emphasizes the importance of responsibility for family and friends.

\section{“Taipei” in Human Condition}

Being "the man who is good at telling stories", Director Wu takes the ordinary people as the characters in his plays. The people's life is the reflection of the development of Taipei. This article tends to find what Taipei is in the characters in the four serial works. Through the characters' behaviors and thoughts, Taipei is defined in its different historical and political periods; its value and influence on the characters reflect the meaning of humans in this city with multiple cultural customs and economic activities. Differences among the people in Taipei are caused by the transformation of the city, including political policy, economic development, and social relationships. The following sections will be concerned respectively with differences in several aspects of the city, taking the serial plays of Human Condition as the discussion.

\section{Differences in the Voices to be Heard: Human Condition 1 and 4}

In the play, some voice is desired to be heard by others. The background of part one is around 2000 when computer technology plays an important role in the industry and economic activities of Taiwan. Internet users are increasing and their lives are dependent on computers. A-mei, the leading female character, complains that computer technology has been part of her family daily life. She is forced to use the computer to play gamble for her father and the neighbors ( $\mathrm{Wu}, 2004, \mathrm{p} .22$ ). The underground gamble activities, in part one, are also practiced through computers. However, virtual technology causes barrier and estrangement among people when they are used to talk by the Internet instead of face-to-face communication and written words. We can see that the poetry demonstration in buses, also mentioned in the first scene, an activity held by the Taipei city government in order to stress the importance and beauty of words, implies that language has lost its original function. The poetry demonstration represents the culture in the urban city, implying that among the silent atmosphere in the public space, people try to identify themselves with what the poetry describe about their attitude toward the city and everyday life. More and more voices are hidden yet desire to be heard.

A-mei's deceased grandmother, Tsuru, tries to express her appreciation for the man, Katsu, who helped her and unravel the misconception when her son blames that she embarrassed him in front of his friends in his childhood. Being a ghost, she can express her feelings and complete her wish only by using her granddaughter's body. The body here becomes a space with function, offering a bridge linking to the secular world. The body is produced with spatiality that interacts with the other spaces. In the bodily space, Tsuru confronts conflicts: she feels amazed when she sees Katsu on TV, who has become an influential entrepreneur in the world. She is struggling about paying a visit since Katsu and the outer world are both different from what she recognizes. Tsuru's contradictive feelings are diminished as the granddaughter instructs her to the new technology and skills with the development of the society. The body she possesses offers the bridge to access to the outer world as well as to break the ice with her son. Also, the granddaughter's generation gap with her father is eliminated by Tsuru, 
using the body as an intermediary space. More importantly, Tsuru's voice is heard; it represents another intrusion to the present life by disclosing misunderstanding to the past events and social inequality in the hierarchical society. It also unfolds people's greediness and ambitious for fame and fortune under the rapid economic development. During the decade between 1990 and 2000, Taipei is constructed as a place of production of various works, making an extremely rapid development by the guidance of technology. Everyday life is composed by multiple social practices and production of relations, including political, economic, social, and cultural activities. Tsuru's reincarnation in the young granddaughter's body proposes a reverberation that capitalism has reorganized our living place, with its own discourse that dominates us.

The fourth part delineates a more capitalistic world. Taipei in this part has been developed into a modern and globalized city. Commercial business and more complicated personal interrelationships develop and display the landscape of this city. The younger sister, Mei-chen, is always the one who tries to control everything. She is the typical character defined by the capitalism in the social relations. She identifies herself within the spatial segregation of different classes, considering that the old and traditional customs should be dissolved. She wants to draw the line from her sister, Mei-nu, who stands for the proletariat class. When Mei-chen accidentally sees Mei-nu working as a contract garbage collector, she pretends that she does not know her (Wu, 2011, p. 65). Furthermore, Mei-chen tries to control everyday life including Mei-nu’s clothing; she dislikes Mei-nu's dress, thinking it rustic. Discarding old and traditional thoughts, Mei-chen attaches to what she thinks modern and advanced concept. $^{3}$

Mei-chen even plays the dominant role in others' relationships. She destroys Mei-nu's love relationship with the doorman of the apartment. She even conducts the arrangement and plan of the apartment, trying to mortgage it because she thinks there is a better opportunity of developing more business apart from the country.

Though being dominated by Mei-chen, who represents the leading discourse of the modern urban space, Mei-nu finally maintains her space. Compared to Mei-chen who focuses on the exchange value of space and always disregards the base of tradition and value of family, even trying to sell the apartment for more investment outside the country, Mei-nu insists on her modest life; she is not so ambitious for a great business and moving forward to the so-called upper-class life. Stable and secure life is enough to her for home is a place with "memories, imagings and dreams" (Cresswell, 2004, p. 24). In the end of the play, the apartment is still the base for Mei-nu's internal recognition of everyday life. Mei-chen finally fails to control the place and continues an unstable life. Feeling irritated, she starts to question what she has been educated since her childhood:

I am always expected to be obedient and to get the best grades and achievement since childhood so that I have to subside and restrict my internal emotion. I have no courage to try any interesting thing. Being a student with only best grades and expectations from parents, there are rivals who compete with me all the time. I have no friends. When my achievement satisfies others, then what can I get? (Wu, 2011, p. 106)

What attitudes Mei-chen takes toward life is based on material value. For better material life and higher exchange value, she constantly pursues changes and controls others by dominating the materials, departing from humanity and virtues. However, her controlling desire declines due to Mei-nu's insistence on preserving family

\footnotetext{
${ }^{3}$ On page 35, Mei-chen is angry with Mei-nu's insistence on joining their uncle's funeral. She thinks it would be find if they just send some flowers to express condolence without being present. Mei-chen reproaches the relatives, including Mei-nu, as old-fashioned and stubborn, who live in the twentieth century but deal with things by the eighteenth century style.
} 
as the supporting basis of everything in life. At the end, Mei-nu's passion for personal love is turned into great philanthropy that tolerates Mei-chen's misbehavior. Mei-chen's aggressive and ambitious voice is overwhelmed by Mei-nu's old-fashioned but humane thinking and life style.

\section{Differences in Transference of Political Power: Human Condition 2}

The historical time of Human Condition 2 in the first half part is from Japanese occupation of Taiwan to $\mathrm{KMT}^{4}$ flee from Mainland China in 1949. This play takes Yuki as the leading character to represent the transformation of political condition during this period. Yuki, raised by Japanese education, confronts the huge change when the sovereignty of Taiwan is transferred to KMT. Tamsui River in the play is the primary and important role in the history of Taipei city. It is the place that people, including the aborigines and the immigrants, start their original connection and relationship with Taipei. Yuki buried her compatriots who were killed in the violent 228 Event in the backyard beside the river, and guards them until her death. She feels that she has the responsibility to take care of her country fellowmen to protect them from abuse and humiliation of KMT armies. Besides the deceased, Yuki spends most of her life protecting her family. In order to prolong the family's life and social position, her marriage has to be linked with Mainlanders whose power is the dominant practice in Taiwan since 1949. Yuki's life is encountering in three periods: Japanese occupation, KMT ruling, and the modern urbanized Taipei. The three periods contain different historical background, political domains, economic and social activities that influence the development of the landscape. The political transformation brings chaos and turbulence that destroys the original system and renews/rebuilds different one. People in this city have to accustom themselves in changing their way of life. Facing transitions, Yuki has to change her language into Mandarin instead of her mother dialect and Japanese so that she can survive under the strict dialect policy ruled by the authority. Besides, when urbanization is greatly developed in Taipei by advanced technology, Yuki learns to use electronic devices to get close to her grandson. She even learns to speak some English phrases that her grandson can understand.

Yet, Yuki insists on some value that should not be diminished. Sense of morality to the dead buried under her house and responsibility for guarding her forefathers' property, including the house, are going to be kept even when she has financial problems. This play describes three periods of Taiwan by presenting Yuki's life. Yuki is the center that connects every event and relationship throughout the play. The three periods are constructed based on patriarchal historical discourse. People's everyday life constructed by ideology, economic and cultural activities are affected and handled by each political authority. Interpreted by Yuki, the female character, it reveals not only man's ruling over the relations of production in space but also woman's subordinated position. Woman is taken as commercial goods such as Yuki's marriage, an exchange for man and the family's stable social status when trading with Mainlanders. Facing the transformative society, Yuki has to adapt herself to the changes. She is, as Lefebvre's thoughts on woman in everyday life, "the most alienated" individual while "the most active resistor" (Highmore, 2002a, p. 126). Yuki is obedient to her parents to help the victims of the 228 Event and accept the planned marriage that brings profit to the family's business and social position. Yet, she has developed her own ways to escape from the dominance and restriction: she learns Mandarin and English, trying to communicate with other people. One of her life routines, having coffee and toast for breakfast, demonstrates that

\footnotetext{
${ }^{4}$ The full name is Kuomintang.
} 
she tries to be distinct from Chinese traditions. Yuki's transformation is like the transition of Taipei, where urban function and activities are changing and development to meet a more open, global and sustainable future. Still, her insistence on morality and responsibility for her country fellowmen cannot be diminished. The growing awareness of humanity strengthens people's thoughts on the future of this city in terms of global competition and national identity such as the Cross-Strait relationships.

\section{Differences in the Development of Economic Activities: Human Condition 3}

The background of Human Condition 3 is based on the initial economic development of Taipei from 1960s to 1970s. Taipei, at that time, was an "agglomeration of productive forces built by labor employed within a temporal process of circulation of capital” (Harvey, 1985, p. 250). People from the rural area moved to Taipei for more job opportunities. By 1987, the population in Taipei is 2.6 million that is the double in 1960s (Taipei City Government, 1988). At that time, the economic activities mostly relied on industries such as steel factories. The government tried to create the "economic miracle" by many infrastructure constructions. ${ }^{5}$ In Taipei, there were many illegitimate factories hiding in residential areas (Huang \& Kwok, 2011, p. 140). The owner of the factory in this play illegally hires three teenagers from Southern Taiwan, insinuating the social condition that during the progress of city construction, many factories hired young people from countryside; in order to pursue fortune and better life, some young people suspended their education and went to Taipei for work. Enduring the owner's insult and abuse, the three young men work hard, trying to earn more money to support their families in the countryside. They hope that one day they can be wealthy as long as they learn skills and begin their own undertakings. With the increase of urban population and economic growth, Taipei is becoming more and more industrialized and commercialized. During 1970s and 1980s, most Taipei people earned their livings by manual labor. Besides factory work, food stands were commonly seen for offering meals to those laborers. Also, street vendors in this city were selling basic daily supplies. More economic activities were in Ximending at that time. Named and set up by Japanese, Ximending was the most important consumer district during this period. “Zonghua Business Building”, near Ximending, built in 1961, was a large commercial area consisted by eight connected buildings. The attached eight buildings contained various industries and business that provided Taipei people with life necessities from food to recreation. Many immigrants from Mainland China started up their business in this area. The three young men in this play mentioned that they hope to make a formal and expensive suit in Zonghua Business Building after they make a great fortune (Wu, 2008, p. 30). Next to Zonghua Business Building is Zhonghua Road and the railroad was parallel to it. The signal sound of railroad crossing in this play implies that the life of characters is near Zhonghua Road. ${ }^{6}$ The railway is also one of the important tools for development of Taiwan's economic.

This play presents different people in the economic turning point of Taiwan. Besides the three young workers, immigrants from Mainland China are also trying to survive since their home has been occupied and ruined by the Communist party. Uncle Shandong, ${ }^{7}$ one of them, for example, sells the hand-made dumplings and

\footnotetext{
${ }^{5}$ Between 1974 and 1979, the “Ten Great Constructions” were exercised for strengthening Taiwan's competition in industries, such as the Taoyuan International Airport, highway, petroleum, and steel industries.

${ }^{6}$ Because of the construction of MRT and railroad underground, Zonghua Business Building was torn down in the 1990s.

7 “Shandong” (Mandarin:山东仔) refers to those who come from the Shandong Province of Mainland China after the Communist Party defeated KMT and takes over the sovereign of the land.
} 
steamed buns which are the traditional food in his hometown. Neighboring with Taiwanese, he tries to settle down in this place although he misses his family. A-shiou, the factory owner's lover, sells the typical Taiwanese food. It is noticeable that in this play there are two kinds of food respectively coming from Mainland China and the local place. They not only offer the characters' need in everyday life but also imply confrontation and combination of different races, cultures, and social interactions in this period. Uncle Shandong and A-shiou, two people with different backgrounds, often communicate in their own languages that certainly make misunderstandings at first but come to compromise with each other after they have mutual feelings about life in this place. They later become support and comfort to each other because they have identified themselves within this city. Due to the urban development, their huts are going to be torn down. In the destruction of the dwelling where they almost live for life, we can see they take care of each other and together fight for their rights of residence (Wu, 2008, pp. 125-126). The three young men come back to support the protest because this place carries the memory of growth in their teenage years:

A-sheng: This place is so strange. People come and go every day. It makes no differences either you are living here permanently or temporarily. All you can remember is the people and events here. Without these people, this place is just like motionless and indifferent stage settings.

A-rong: I have that feeling, too. The city will mean nothing to me if there is no one living here. (Wu, 2008, p. 123)

The space is meaningless and insignificant if there is no man. Human is the subject in the space that dominates the operation of everything. The meaning is endowed by human depending on how human thinks, arranges, and carries out the everyday life in the space. Doreen Massey argues that city can be explained as a space containing "many different physical features, and many different experiences, about which many stories can be told" (Massey, Allen, \& Pile, 1999, p. 12). As Mumford takes city as a theater implying there a "geographic plexus, an economic organization, an institutional process" (Mumford, 1937, p. 185) and social actions connected here. City is a way of life, establishing a network by which people gather in this space and create various activities and social relationships. In this network, we can see how power relationship decides the development and expansion of city. In this play, the destruction of the old community and people's location and re-location because of new plan and rearrangement for this space, we see how people face transformation of their surroundings and their nostalgic feelings of cherishing humanity in the renewal life.

\section{Conclusion}

Literature is a way of representation of our everyday life. Works that describes the ordinary people can enlighten our mind when we feel doubtful or frustrated about the life. In Human Condition, the playwright tries to assert morality, love and care of brotherhood as the essential value no matter what the society encounters. The characters in the play are the ordinary people like any one of us. Watching the play is watching our life in which we identify ourselves with the characters and the daily events. Taipei is the mainly place that the background of this play occurs. The transformation of the city is represented in the relationships and social production of the characters and the political and economic activities. As the capital, Taipei is a conglomeration of people and systems under the influence from historical, social, and cultural events. People with different backgrounds encounter here; they have conflicts and negotiations. As this place is urbanized, the mutual feelings among 
people are diminishing. People are alienated from one another. Human Condition offers some reflections in respecting differences by the multiple social and cultural aspects composed in this city. This creative work attracts many attentions from the young to the elder people. It is a successful work in the cultural industry: it enlightens us by dealing with the most ordinary life events.

City is a product of human nature (Park 1). The importance and essence of city is to offer places like schools, government, bus station, hospitals in which it gathers people and "makes a difference to what goes on between them" (Massey et al., 1999, p. 42). City is the place of encounters that people interact among one another in this space. In the encounters, both in relative relationships and community mutual feelings, differences are produced. The experiences of hospitality, rejection, conflict, communication, compromises, and identification bring people new forms of interaction and differences that offer "new opportunities for people to live their lives differently" (Massey et al., 1999, p. 48).

\section{References}

Cresswell, T. (2004). Place: A short introduction. Oxford: Blackwell.

Gottdiener, M. (1985). The social production of urban space. Austin: University of Texas Press.

Hamnett, S., \& Forbes, D. (2011). Planning Asian cities: Risks and resilience. London: Routledge.

Harvey, D. (1973). Social justice and the city. London: Edward Arnold.

Harvey, D. (1985). The urbanization of capital: Studies in the history and theory of capitalist urbanization (Vol. 2). Baltimore: Johns Hopkins University Press.

Highmore, B. (2002a). Everyday life and cultural theory: An introduction. London: Routledge.

Highmore, B. (2002b). The everyday life reader. London: Routledge.

Huang, L., \& Kwok, R. Y. W. (2011). Taipei’s metropolitan development: Dynamics of cross-strait political economy, globalization and national identity. In S. Hamnett, \& D. Forbes (Eds.), Planning Asian cities: Risks and resilience (pp. 131-157). London: Routledge.

Lefebvre, H. (1984). Everyday life in the modern world. In S. Rabinovitch (Trans.). New Brunswick: Transaction Publishers.

Lefebvre, H. (1991). Critique of everyday life. In J. Moore (Trans.). London: Verso.

Lefebvre, H. (1992). The production of space. Oxford: Blackwell.

Lefebvre, H. (1996). The right to the city. In E. Kofman, \& E. Lebas (Eds.), Writing on cities (pp. 147-159). Oxford: Blackwell.

Lefebvre, H. (2003). Henri Lefebvre: Key writings. New York: Continuum.

LeGate, R. T., \& Frederic, S. (1937). The city reader. London: Routledge.

Malpas, J. (1999). Place and experience: A philosophical topography. Cambridge: Cambridge UP.

Massey, D., Allen, J., \& Pile, S. (1999). City worlds. London: Routledge.

Mumford, L. (1937). What is a city? In R. T. LeGates, \& F. Stout (Eds.), The city reader (pp. 184-189). London: Routledge.

Park, R. E. (1984). The city: Suggestion for investigation of human behavior in the urban environment. In R. E. Park et al. (Eds.), The city: Suggestion for investigation of human behavior in the urban environment (pp. 1-46). Chicago: University of Chicago Press.

Stanek, L. (2011). Henri Lefebvre on space: Architecture, urban research, and the production of theory. Minneapolis: University of Minnesota Press.

Taipei City Government. (1988). The 20th year of anniversary of Taipei jurisdiction expansion. Taipei: Bureau of Information, Taipei City Government.

Wu, N. J. (2004). Human condition. Taipei: Eurasian Press.

Wu, N. J. (2007). Human condition 2: She and men in her life. Taipei: Eurasian Press.

Wu, N. J. (2008). Human condition 3: Midnight at Taipei . Taipei: Eurasian Press.

Wu, N. J. (2011). Human condition 4: The same moonlight. Taipei: Eurasian Press. 